\title{
Detection of circulating tumor cells: Clinical relevance of a novel metastatic tumor marker (Review)
}

\author{
CHUANLI REN ${ }^{1}$, CHONGXU HAN $^{1}$, DAXIN WANG $^{1}$, XIAOHANG ZHAO $^{2}$, \\ GUANGFU JIN $^{3}$ and HONGBING SHEN ${ }^{3}$
}

\begin{abstract}
${ }^{1}$ Clinical Laboratory, Medical College of Yangzhou University, Yangzhou; ${ }^{2}$ State Key Laboratory of Molecular Oncology, Cancer Institute and Hospital, Chinese Academy of Medical Sciences and Peking Union Medical College, Beijing; ${ }^{3}$ Department of Epidemiology and Biostatistics, Cancer Center of Nanjing Medical University, Nanjing, P.R. China
\end{abstract}

Received December 2, 2010; Accepted February 8, 2011

DOI: $10.3892 /$ etm.2011.234

\begin{abstract}
Most cancer-related deaths are caused by the hematogenous spread of cancer cells to distant organs and their subsequent metastasis. During the early stages of the metastatic cascade, cancer cells disseminate from the primary site via the lymphatic vessels and/or by hematogenous routes. Circulating tumor cells (CTCs), cancer cells that have disseminated into the systemic circulation, may be a predictor of poor prognosis in several carcinomas. An understanding of the molecular mechanisms involved in the blood-borne dissemination of cancer cells may help to clarify the process of metastasis and provide a powerful and non-invasive approach for anticancer treatments that are tailored to individual patients.
\end{abstract}

\section{Contents}

1. Introduction

2. Malignant features of metastatic CTCs

3. Methods for separating CTCs

4. CTC enrichment

5. CTC identification

6. CTCs and cancer stem cells

7. Clinical relevance of CTCs

8. Advanced tools for tailored therapy?

9. Concluding remarks

\section{Introduction}

Metastasis to distant sites (e.g., lungs, liver, bone and brain) via the bloodstream or lymph nodes is a major cause of

Correspondence to: Dr Chuanli Ren, Clinical Laboratory, Northern Jiangsu People's Hospital and Medical College of Yangzhou University, Yangzhou, Jiangsu 225001, P.R. China

E-mail: renchl@163.com

Key words: circulating tumor cells, solid tumors, epithelial mesenchymal transition, prognosis cancer-related mortality (1-3). Circulating tumor cells (CTCs) play an important role in cancer relapse and metastasis. CTCs identical to those in primary tumors were first discovered by Ashworth as early as 1869 (4), and were later regarded as a hallmark of the 'leukemic phase' of cancer (5). CTCs were proposed as a novel minimally invasive prognostic and predictive marker that reflects the biological characteristics of tumors, and have been the subject of an increasing number of clinical studies. Identifying cancer cells among the millions of normal blood cells during the early stages of cancer, however, is challenging. In recent years, many new methods have been developed to enrich and detect these rare CTCs in peripheral blood (6-13). The different technologies involved, coupled with the heterogeneity of the screened populations, make the clinical significance of CTCs difficult to interpret (7). Thus, it is necessary to standardize the detection methods used to identify CTCs in order to determine their biological and clinical relevance. The detection of dynamic changes and malignant features within these rare cells is closely associated with the efficacy of therapy and with prognosis $(6,14-24)$. CTCs may play an important role in the detection of early relapse and in the assessment of prognosis and the efficacy of the chosen therapy for both established cancers and metastatic precursor cells.

\section{Malignant features of metastatic CTCs}

Occult tumor cells may persist in a dormant or low proliferative state after curative therapy. It is these cells that are responsible for tumor relapse and metastasis. Such cells, which are not detectable by current routine diagnostic methods, may play an important role in recurrence as they may express different biological characteristics and/or markers from those of the primary tumor (25). Therefore, the detection and characterization of CTCs is of the utmost clinical relevance. The processes by which cancer cells proliferate [angiogenesis, detachment from the primary tumor, epithelial to mesenchymal transition (EMT) and intravasation into the vasculature followed by extravasation into distal organs] are not yet fully understood (Fig. 1). As cancer cells invade through the basement membrane, they undergo EMT and are shed into the circulation. This process is vital for metastasis. 
Table I. Detection of CTCs in solid tumors and prognosis.

\begin{tabular}{|c|c|c|c|c|c|c|c|}
\hline Tumor type & TNM & Samples (n) & Methods & Markers & $\begin{array}{l}\text { Positivity of } \\
\text { CTC }(\%)\end{array}$ & Prognosis & Refs. \\
\hline Breast cancer & IV & 80 & CellSearch & $\begin{array}{l}\mathrm{Ck} 8 / 18 / 19^{+} \\
\mathrm{CD} 45^{-} \text {cells }\end{array}$ & 61.0 & PFS & 16 \\
\hline Breast cancer & IV & 177 & CellSearch & $\begin{array}{l}\mathrm{CK} 8 / 18 / 19^{+} \\
\mathrm{CD}^{-} 5^{-} \text {cells }\end{array}$ & 49.0 & $\begin{array}{l}\text { PFS } \\
\text { OS }\end{array}$ & 19 \\
\hline Breast cancer & I-II & 148 & RT-PCR & CK19 mRNA & 29.7 & $\begin{array}{l}\text { DFS } \\
\text { OS }\end{array}$ & 66 \\
\hline Breast cancer & I-II & 444 & RT-PCR & CK19 mRNA & 40.8 & $\begin{array}{l}\text { DFS } \\
\text { OS }\end{array}$ & 67 \\
\hline Hepatic cancer & I-IV & 101 & RT-PCR & Albumin mRNA & 45.0 & $\begin{array}{l}\text { DFS no } \\
\text { OS no }\end{array}$ & 78 \\
\hline Colorectal cancer & I-IV & 196 & RT-PCR & $\begin{array}{l}\text { CEA, } \\
\text { CK19 mRNA }\end{array}$ & 85.0 & PFS & 68 \\
\hline Colorectal cancer & I-II & 66 & RT-PCR & CEA mRNA & 54.5 & OS no & 79 \\
\hline Colorectal cancer & IV & 413 & CellSearch & $\begin{array}{l}\text { CK8/18/19+ } \\
\text { CD45- cells }\end{array}$ & $26 \geq 3$ CTCs & $\begin{array}{l}\text { OS } \\
\text { PFS yes }\end{array}$ & 51,69 \\
\hline Prostate cancer & IV & 162 & RT-PCR & PSA mRNA & 44.0 & OS & 70 \\
\hline Bladder cancer & T1G3 & 54 & RT-PCR & Survivin mRNA & 44.0 & PFS & 76 \\
\hline $\begin{array}{l}\text { Non-small cell } \\
\text { lung cancer }\end{array}$ & I-II & 61 & RT-PCR & $\begin{array}{l}\text { TIF-1 } \\
\text { CK19 mRNA }\end{array}$ & $\begin{array}{l}36.1 \\
42.6\end{array}$ & PFS & 77 \\
\hline
\end{tabular}

PFS, progression-free survival; OS, overall survival; DFS, disease-free survival.

Due to changes in the microenvironment and destruction by shearing forces in the blood vessels and by immune cells, most CTCs in the circulation undergo apoptosis. The result is that only a very small proportion of CTCs survive (5). However, given ideal conditions, they may extravasate and develop into micrometastases (26). A mouse model of tumor metastasis showed that $10^{6}$ cancer cells were shed into the blood stream every day, and that most of these failed to form metastases due to cellular apoptosis (27).

The malignant phenotype of CTCs is closely related to their metastatic tendency. CTCs derived from breast cancer, renal cell carcinoma, prostate cancer, colon cancer and melanoma have been shown to be malignant by analyzing the aneusomy of chromosomes $1,3,4,7,8,11$ or 17 using dual or tricolor fluorescence in situ hybridization (FISH) $(28,29)$. During the early stages of tumor formation, hypoxia triggers neovascularization within the lesions, which facilitates tumor dissemination via the blood vessels. This process occurs prior to proliferation and, of course, before the appearance of clinical symptoms in the patients (30). Therefore, early detection of CTCs may enable the early diagnosis of cancer. As CTCs are shed into the blood of breast cancer patients every few hours, apoptotic CTCs are replenished by cells originating from the primary tumor, thus maintaining a balance between apoptotic and proliferating CTCs. Several CTCs may remain in the circulation for up to 22 years, which may explain tumor dormancy (31).

Studies of the signaling pathways within CTCs have found that breast cancer CTCs co-express p-FAK, p-PI3K and HER2, suggesting that they possess activated protein kinases, which regulate their metastatic ability $(32,33)$. Analysis of these proliferative or metastatic signaling pathways may help to elucidate the mechanisms underlying the malignant biology of CTCs.

Whether CTCs metastasize to other organs depends on their genetic profile. The metastatic potential of CTCs is closely related to their heterogeneity, the microenvironment and the efficiency of the patient's immune system. The immune system sees CTCs as 'foreign', but many CTCs escape immune surveillance and manage to form micrometastases and macrometastases in distant organs (34).

\section{Methods for separating CTCs}

Recent technological advances in the detection and characterization of CTCs have proven helpful in understanding the biology and clinical significance of these rare cells. Many methods can be used to enrich and identify CTCs (35), such as immunomagnetic cell enrichment (which includes magnetic activated cell separation; MACS) (36), the CellSearch system, isolation by the size of epithelial tumor cells (ISET) $(37,38)$, epithelial immunospot (EPISPOT), immunological assays based on enzyme-linked immunosorbent assay (ELISPOT) technology (7) and microchips that enrich CTCs from millions of white blood cells $(12,13)$ (Table I).

\section{CTC enrichment}

CTCs in the peripheral blood of patients with solid tumors are rare, and so the sensitivity and specificity of detection is dependent upon the particular technological approach used. 


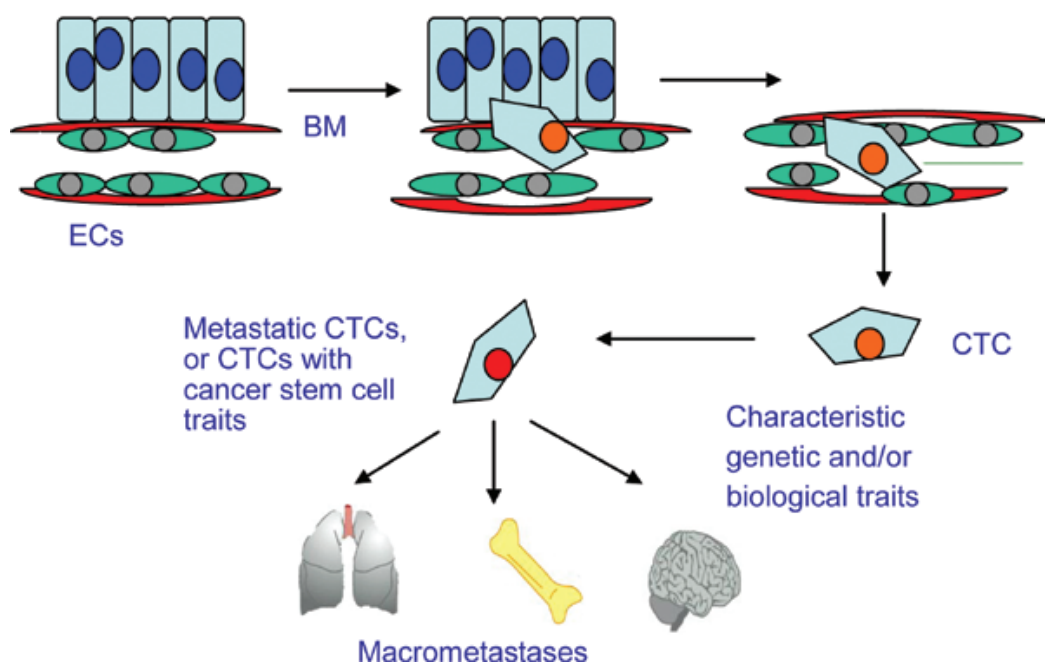

Figure 1. The process of CTC metastasis. Cancer cells with localized invasion require epithelial mesenchymal transition (EMT), by which adherent cancer cells achieve the ability to migrate, as well as with the loss of integrity of the basement membrane (BM) and the extracellular matrix (ECM). The process permits some metastatic cancer cells to intravasate into the blood. CTCs interact with the microenvironment in the circulation. Finally, only a small proportion of CTCs with the ability to metastasize, or those with traits similar to those of cancer stem cells, are thought to extravasate to distal organs and develop macrometastases. Genetic and molecular analysis of these rare cells may provide a novel tool for evaluating their biological and clinical relevance.

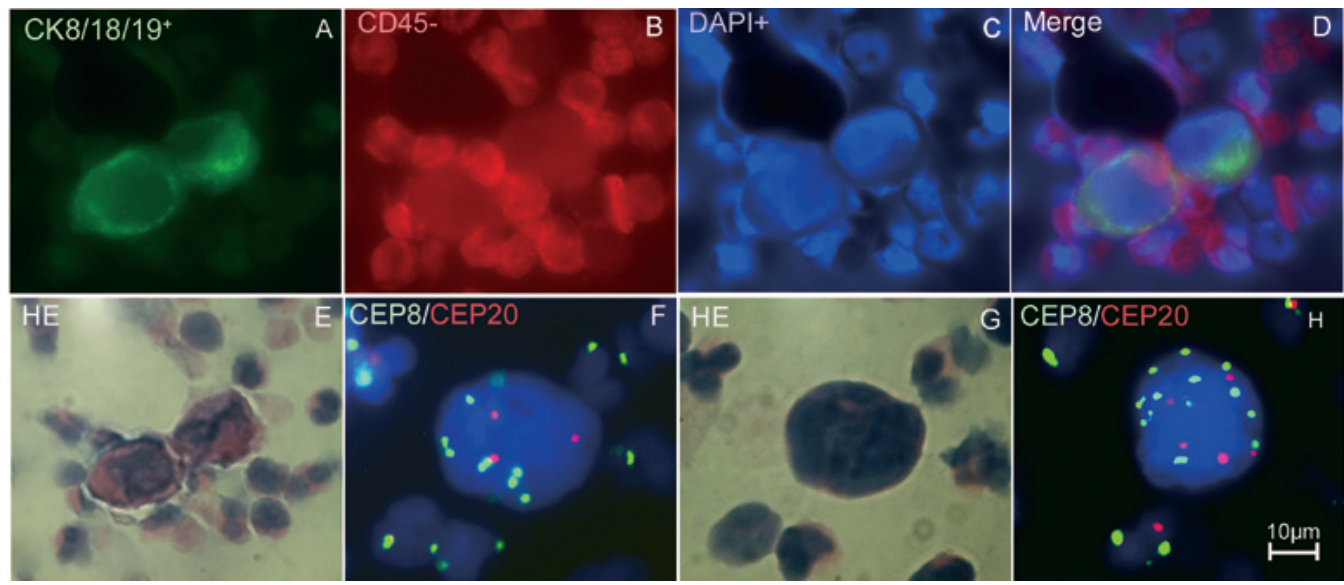

Figure 2. Enrichment and identification of CTCs. CTCs were stained with (A) anti-cytokeratin 8/18/19-Alexa 488-positive, (B) anti-CD45-Alexa 594-negative, (C) 4,6-diamidino-2-phenylindole (DAPI)-positive antibodies. (D) Merged image of A, B and C; (E and G) CTCs re-stained with Hematoxylin and Eosin (H\&E). (F and H) CTCs hybridized with DNA probes targeting specific chromosome 8 (green) and chromosome 20 (red), showing polysomy of chromosomes 8 and 20. Original magnification, $\mathrm{x} 100$. Scale bar, $10 \mu \mathrm{m}$.

In the past, immunomagnetic methods of enrichment have been widely used $(9,11)$. Basically, these techniques involve either positive or negative selection of the chosen cell type. For positive selection, beads are linked to the epithelial antibody, EpCAM, to enrich the rare cells. For negative selection, beads are linked the common leukocyte antigen, CD45, in order to deplete the hematopoietic cells (11). Positive enrichment systems include the CellSearch system (approved by the FDA in 2004), CTC-chips, MACS (when used for positive selection) and the OncoQuick system. The major negative enrichment system is MACS. Although many methods enable the isolation of CTCs with an epithelial phenotype, such as EpCAM and CK antigen expression, the disadvantage is that epithelial proteins are down-regulated during EMT (39), which may affect the efficiency of CTC detection (Fig. 2). Therefore, positive enrich- ment strategies may not detect EpCAM-negative CTCs (40). A comparison of two different methods for enumerating CTCs in carcinoma patients showed that the CellSearch system (mean detection rate, $20 \mathrm{CTCs} / 7.5 \mathrm{ml}$ of blood) is a more accurate and sensitive method for enumerating CTCs than the OncoQuick system (mean detection rate 3, CTCs/7.5 ml; P<0.0001) $(41,42)$.

The newly developed microchip technology provides the highest detection rate for CTCs. The chip separates CTCs from whole blood using EpCAM-coated micro-posts under controlled laminar flow conditions to ensure optimal interaction between the cells $(12,35,43)$. The purity of the CTCs was found to be $>100$ times that obtained using other methods (12). However, this enrichment system requires further clinical validation of its accuracy. In cancer cell spiking experiments using the CellSearch system, recovery rates were 85 and $92 \%$, respec- 
Table II. Methods for CTC analysis.

\begin{tabular}{|c|c|c|c|c|c|c|}
\hline System & $\begin{array}{l}\text { Blood volume } \\
\text { per test }(\mathrm{ml})\end{array}$ & $\begin{array}{l}\text { Principle of } \\
\text { enrichment }\end{array}$ & $\begin{array}{l}\text { Principle of } \\
\text { identification }\end{array}$ & Sensitivity & $\begin{array}{l}\text { Recovery } \\
\text { rate }(\%)\end{array}$ & Refs. \\
\hline OncoQuick & $10-15$ & $\begin{array}{l}\text { Density centrifugation } \\
\text { and a porous barrier } \\
\text { membrane }\end{array}$ & $\begin{array}{l}\text { Cytometry } \\
\text { or RT-PCR }\end{array}$ & $1 \mathrm{CTC} / 9.5 \times 10^{4} \mathrm{WBC}$ & $70-90$ & 41,42 \\
\hline ISET & 10 & Cell size & CK19 RT-PCR & $1 \mathrm{CTC} / 2 \times 10^{6} \mathrm{WBC}$ & NS & 37,38 \\
\hline MACS & $5-16$ & $\begin{array}{l}\text { Depletion of leukocytes } \\
\text { or enrichment of } \\
\text { epithelial originated cells } \\
\text { using immunobeads }\end{array}$ & CK8/18+ cells & $1 \mathrm{CTC} / 1 \times 10^{6} \mathrm{WBC}$ & NS & 36 \\
\hline $\begin{array}{l}\text { CellSearch } \\
\text { (Veridex) }\end{array}$ & 7.5 & $\begin{array}{l}\text { Beads coated } \\
\text { with EpCAM }\end{array}$ & $\begin{array}{l}\text { CK8/CK } 18 / \text { CK } 19^{+} \\
\text {and CD45- cells }\end{array}$ & $1 \mathrm{CTC} / 1 \times 10^{7} \mathrm{WBC}$ & 85 & 45 \\
\hline CTC microchip & 5 & $\begin{array}{l}\text { Microposts coated } \\
\text { with EpCAM }\end{array}$ & $\begin{array}{l}\text { CK8/CK } 18 / \text { CK } 19^{+} \\
\text {and CD } 45^{-} \text {cells }\end{array}$ & $1 \mathrm{CTC} / 1 \times 10^{7} \mathrm{WBC}$ & $>65$ & 43 \\
\hline FAST & & $\begin{array}{l}\text { Beads coated } \\
\text { with EpCAM }\end{array}$ & $\mathrm{CK}^{+}$cells & $10^{-6}$ & $>86$ & 57 \\
\hline
\end{tabular}

NS, non-significant (data not shown). WBC, white blood cells.

tively, from two different patient groups $(44,45)$. New CTC-chip micro-fluidic technology showed a 10- to 100-fold improvement in CTC yield from patient samples over the CellSearch system (44). However, this method needs further validation using large numbers of clinical samples. Since not all CTCs express EpCAM, the use of magnetic beads labeled with both CD146 and EpCAM antibodies increases the rate of detection (46).

\section{CTC identification}

The key to successfully identifying CTCs is differentiating them from other hematopoietic cells and squamous cells. CTCs can be identified as malignant by cytomorphology, tumor-specific antigen expression and aneusomy of the chromosomes (47). The techniques used to identify CTCs are broadly divided into cytometric- and nucleic acid-based approaches (Table II). Cytometric approaches use immunocytochemical methods to characterize individual tumor cells. Nucleic acid-based approaches detect DNA or RNA sequences that are differentially expressed in tumor cells and normal controls (11). However, pseudogenes or non-specific sequences may be identified using nucleic acid-based approaches. When the efficacy of the therapy or the tumor burden is to be evaluated, nucleic acid-based approaches may be a simple and straightforward choice. If intact cellular morphology and genetic phenotype are to be studied, cytometric approaches may be preferred (48). FISH has been used to directly identify circulating genetically abnormal cells (CACs) in the peripheral blood of patients with non-small cell lung cancer. Depending on the expression levels of abnormal biomarkers, up to 45 CACs per microliter were detected, compared to $<10 \mathrm{CACs}$ per milliliter in most studies using immunomagnetic beads (22,49-53). Peripheral blood-based membrane-array assays with a panel of tumor-related mRNA markers (hTERT, CK-19, CEA and MUC1) were used to identify CTCs in gastric cancer patients using a nucleic acid-based approach
(54). This technique has a satisfactory level of sensitivity and specificity (54). In vivo, non-invasive label-free detection and eradication of circulating metastatic melanoma cells using two-color photoacoustic flow cytometry and a diode laser has also been attempted (55). Additionally, GFP-expressing virusbased methods are remarkably simple and allow the precise enumeration of viable CTCs (56). Another approach used is fiber-optic array scanning technology (FAST), which applies laser-printing techniques to the detection of rare CTCs. The combination of FAST enrichment and automated digital microscopy (ADM) imaging yields the level of performance required for the reliable detection of metastatic colorectal cancer cells in the blood $(57,58)$. Further testing using clinical samples and integration of all the modules into a single, fully automated smart miniaturized system will enable minimally invasive testing for the detection and characterization of CTCs (25).

\section{CTCs and cancer stem cells}

The cancer stem cell theory suggests that only a small fraction of cancer cells are stem cells capable of self-differentiation and self-replication. A few hundred cancer stem cells (CSCs) were found to cause carcinogenesis in NOD/SCID mice, whereas non-cancer stem cells did not (3). The proposed existence of rare CSCs within an ordinary tumor cell population with limited proliferative potential implies that such rare progenitors have the real ability to metastasize (59). CD133, CD $44^{+} /$ CD24-/low and CXCR4 have been proposed as markers for CSCs in glioma, breast, colon, prostate, pancreatic and esophageal cancer (60). CD133 mRNA detected in the peripheral blood of patients with colon cancer is a predictor of poor prognosis (61). CD $44^{+} / \mathrm{CD} 24^{-/ \text {low }}$ CTCs have also been identified in the peripheral blood of patients with breast cancer. These putative CSC marker-positive CTCs have been associated with tumor metastasis (62). At present, the relationship between CSCs and 
CTCs is not clear. Further research is required to validate any relationship and their clinical relevance.

\section{Clinical relevance of CTCs}

CTCs may predict tumor relapse, therapeutic efficacy and/ or prognosis (Table I). The results of one study found that in case of lung cancer metastasis to distant organs, the number of CTCs clearly increased (63). CTCs may also be surrogate markers for early tumor metastasis (63). In several carcinomas, peripheral blood CTCs were found to be a predictor of poor prognosis $(24,64)$. Cristofanilli et al analyzed CTCs in the peripheral blood of 177 metastatic breast cancer patients enrolled in multi-center double-blind prospective studies. The results showed that a detection rate of $\geq 5$ CTCs $/ 7.5 \mathrm{ml}$ peripheral blood indicated a worse prognosis than a rate of $<5$ CTCs/7.5 ml. CTC dynamics clearly reflected the efficacy of the chosen therapy (19). The basal level of CTCs is a good prognostic indicator, and changes in CTC levels during treatment may reflect the efficacy of the chosen therapy (16). A retrospective study revealed a relationship between the overall survival rate of 37 prostate cancer patients and CTC levels; the overall survival rate of patients with $\geq 5 \mathrm{CTCs} / 7.5 \mathrm{ml}$ peripheral blood was 0.7 years compared to 4 years for patients with $<5 \mathrm{CTCs} / 7.5 \mathrm{ml}(\mathrm{P}=0.002)$ (65). In patients with breast cancer, CTCs were still detectable in the peripheral blood after the primary tumor was eradicated, and the risk of recurrence in these patients was greater than for those with no detectable CTCs (19). The detection of CK19 mRNA-positive CTCs in the peripheral blood of patients with stage I or II breast cancer prior to adjuvant therapy was an independent prognostic indicator of poor clinical outcome (66), mainly in those patients with ER-negative, triple-negative and HER2-positive earlystage breast cancer (67). CK20 mRNA-positive CTCs detected within $24 \mathrm{~h}$ of primary colorectal cancer resection were also found to be a strong predictor of recurrence (68).

The number of CTCs detected by the CellSearch system before and during treatment was found to be an independent predictor of progression-free survival and overall survival in patients with metastatic colorectal cancer. This implies that CTCs may provide prognostic information in addition to the results obtained from imaging studies $(51,69)$. Detection of PSA-positive CTCs is a significant prognostic factor for survival in patients with hormone refractory prostate cancer (70). EGFR expression by CTCs in patients with metastatic breast cancer was also used as a predictive marker for targeted therapy (71). The greatest number of CTCs was detected in patients with esophageal cancer immediately after surgery and correlated with the rate of tumor relapse (72). Wild-type KRAS, detected in CTCs from patients with metastatic colon cancer, strongly correlated with their sensitivity to chemotherapy and with prognosis $(73,74)$. Apoptotic CTCs can be detected in the peripheral blood of patients with prostate cancer after chemotherapy, which may reflect treatment efficacy (75). The presence of surviving CTCs is also an independent prognostic factor in patients with T1G3 bladder cancer (76). Another study demonstrated that TTF-1 mRNAexpressing CTCs may be a useful surrogate predictor of disease progression before clinical symptoms are apparent in non-small cell lung cancer (77).
However, in some solid tumors, the detection of CTCs in the peripheral blood does not predict prognosis. For example, circulating albumin mRNA failed to provide significant information regarding the diagnosis and prognosis of hepatocellular carcinoma (78), and the postoperative detection of blood CTCs using CEA mRNA had no prognostic significance in patients with colorectal cancer after surgical resection (79). The use of CTCs as prognostic indicators in some carcinomas is unreliable. This may be due to the different methods used to detect them and the different populations studied.

\section{Advanced tools for tailored therapy?}

Dynamic molecular analysis of CTCs may be helpful for targeting therapy in individual patients. HER 2 expression is not increased in the primary tumor during the early stages of breast cancer, but increased expression can be detected in CTCs in advanced breast cancer. This may be why patients treated with herceptin have a good prognosis (80). The molecular genetics of CTCs are similar to those of the primary tumor. Therefore, CTCs may represent the status of the primary tumor (81). Nearly $98 \%$ of patients with HER2-positive primary and metastatic cancers had CTCs expressing elevated levels of HER2. However, $33 \%$ of patients, in whom the primary cancer was HER2-negative, had CTCs that were HER2-positive (44). This suggests that HER 2 expression by CTCs may provide the rationale for individually targeted HER 2 therapy $(80,82,83)$. Serial analysis of CTCs illustrates the molecular evolution of the primary tumor during the course of treatment. It may also have another advantage: even once the primary tumor is eradicated, CTCs continue to provide a 'real-time' non-invasive method of cancer cell genotyping.

CTC detection in peripheral blood is convenient, rapid and reproducible. Analyzing the characteristics of CTCs may help to evaluate the efficacy of therapy, provide a unique diagnostic resource and predict prognosis (84). Enumeration and identification of CTCs undergoing apoptosis may provide relevant information about responses to therapy in prostate cancer patients (75). Although the size of the tumor and the progress of the disease can be evaluated by radiography, its sensitivity is limited. The opportunity for tumor eradication is often lost due to the late detection of metastases by radiography (85). CTC monitoring is an early reproducible indication of disease status, superior to current imaging methods. Moreover, CTC levels appear to be superior to conventional imaging methods (even PET-CT) for evaluation of the response to treatment (86).

\section{Concluding remarks}

Since the phenotype and genotype of metastatic cancer cells are quite different from those of the primary tumor, CTC levels provide a more accurate method of evaluating the efficacy of chemotherapy and targeted therapy than analysis of the primary tumor (80). When significant CTC levels are confirmed, it may guide the treatment of patients who need adjuvant therapy, as a reasonable estimate can be made as to whether CTCs have been cleared from the peripheral blood. Tumor malignancy is associated with complex signaling pathways; therefore, it is desirable that CTCs be used as a tool to forecast prognosis, preferably in combination with another index, to comprehensively 
monitor their clinical relevance $(2,55)$. Detection, monitoring and molecular analysis of CTCs may provide a non-invasive approach to the detection of early tumor dissemination and the assessment of prognosis and appropriate treatment for established cancers (1). As more and more standardized and effective methods are established and the molecular mechanisms involved in metastasis are elucidated, and as more multi-center large sample clinical trials are validated, CTCs may be used as a real-time tool for the tailored treatment of cancer patients.

\section{Acknowledgements}

This study was supported by the Jiangsu Provincial Health Department Science Foundation (H200970).

\section{References}

1. Maheswaran S and Haber DA: Circulating tumor cells: a window into cancer biology and metastasis. Curr Opin Genet Dev 20: 96-99, 2010.

2. Pantel K, Alix-Panabieres C and Riethdorf S: Cancer micrometastases. Nat Rev Clin Oncol 6: 339-351, 2009.

3. Pantel K, Brakenhoff RH and Brandt B: Detection, clinical relevance and specific biological properties of disseminating tumour cells. Nat Rev Cancer 8: 329-340, 2008.

4. Ashworth A: A case of cancer in which cells similar to those in the tumours were seen in the blood after death. Aust Med J 14: 146-149, 1869.

5. Mocellin S, Keilholz U, Rossi CR and Nitti D: Circulating tumor cells: the 'leukemic phase' of solid cancers. Trends Mol Med 12: 130-139, 2006.

6. Peach G, Kim C, Zacharakis E, Purkayastha S and Ziprin P: Prognostic significance of circulating tumour cells following surgical resection of colorectal cancers: a systematic review. Br J Cancer 102: 1327-1334, 2010.

7. Alunni-Fabbroni M and Sandri MT: Circulating tumour cells in clinical practice: methods of detection and possible characterization. Methods 50: 289-297, 2010.

8. Allan AL and Keeney M: Circulating tumor cell analysis: technical and statistical considerations for application to the clinic. J Oncol 2010: 426218, 2010.

9. Panteleakou Z, Lembessis P, Sourla A, et al: Detection of circulating tumor cells in prostate cancer patients: methodological pitfalls and clinical relevance. Mol Med 15: 101-114, 2009.

10. Dotan E, Cohen SJ, Alpaugh KR and Meropol NJ: Circulating tumor cells: evolving evidence and future challenges. Oncologist 14: 1070-1082, 2009.

11. Ring A, Smith IE and Dowsett M: Circulating tumour cells in breast cancer. Lancet Oncol 5: 79-88, 2004.

12. Nagrath S, Sequist LV, Maheswaran S, et al: Isolation of rare circulating tumour cells in cancer patients by microchip technology. Nature 450: 1235-1239, 2007.

13. Sequist LV, Nagrath S, Toner M, Haber DA and Lynch TJ: The CTC-chip: an exciting new tool to detect circulating tumor cells in lung cancer patients. J Thorac Oncol 4: 281-283, 2009.

14. Cristofanilli M: The biological information obtainable from circulating tumor cells. Breast 18 (Suppl 3): 38-40, 2009.

15. Botteri E, Sandri MT, Bagnardi V, et al: Modeling the relationship between circulating tumour cells number and prognosis of metastatic breast cancer. Breast Cancer Res Treat 122: 211-217, 2010.

16. Nole F, Munzone E, Zorzino L, et al: Variation of circulating tumor cell levels during treatment of metastatic breast cancer: prognostic and therapeutic implications. Ann Oncol 19: 891-897, 2008.

17. Apostolaki S, Perraki M, Pallis A, et al: Circulating HER2 mRNA-positive cells in the peripheral blood of patients with stage I and II breast cancer after the administration of adjuvant chemotherapy: evaluation of their clinical relevance. Ann Oncol 18: 851-858, 2007.

18. Cristofanilli M, Hayes DF, Budd GT, et al: Circulating tumor cells: a novel prognostic factor for newly diagnosed metastatic breast cancer. J Clin Oncol 23: 1420-1430, 2005.
19. Cristofanilli M, Budd GT, Ellis MJ, et al: Circulating tumor cells, disease progression, and survival in metastatic breast cancer. $\mathrm{N}$ Engl J Med 351: 781-791, 2004.

20. Takeuchi $\mathrm{H}$ and Kitagawa Y: Circulating tumor cells in gastrointestinal cancer. J Hepatobiliary Pancreat Surg 17: 577-582, 2010.

21. Xenidis N, Ignatiadis M, Apostolaki S, et al: Cytokeratin-19 mRNA-positive circulating tumor cells after adjuvant chemotherapy in patients with early breast cancer. J Clin Oncol 27: 2177-2184, 2009

22. Wu C, Hao H, Li L, et al: Preliminary investigation of the clinical significance of detecting circulating tumor cells enriched from lung cancer patients. J Thorac Oncol 4: 30-36, 2009.

23. Wong SC, Chan CM, Ma BB, et al: Clinical significance of cytokeratin 20-positive circulating tumor cells detected by a refined immunomagnetic enrichment assay in colorectal cancer patients. Clin Cancer Res 15: 1005-1012, 2009.

24. Scher HI, Jia X, de Bono JS, et al: Circulating tumour cells as prognostic markers in progressive, castration-resistant prostate cancer: a reanalysis of IMMC38 trial data. Lancet Oncol 10: 233-239, 2009.

25. Stakenborg T, Liu C, Henry O, et al: Automated genotyping of circulating tumor cells. Expert Rev Mol Diagn 10: 723-729, 2010.

26. Luzzi KJ, MacDonald IC, Schmidt EE, et al: Multistep nature of metastatic inefficiency: dormancy of solitary cells after successful extravasation and limited survival of early micrometastases. Am J Pathol 153: 865-873, 1998.

27. Chang YS, di Tomaso E, McDonald DM, Jones R, Jain RK and Munn LL: Mosaic blood vessels in tumors: frequency of cancer cells in contact with flowing blood. Proc Natl Acad Sci USA 97: 14608-14613, 2000.

28. Shaffer DR, Leversha MA, Danila DC, et al: Circulating tumor cell analysis in patients with progressive castration-resistant prostate cancer. Clin Cancer Res 13: 2023-2029, 2007.

29. Fehm T, Sagalowsky A, Clifford E, et al: Cytogenetic evidence that circulating epithelial cells in patients with carcinoma are malignant. Clin Cancer Res 8: 2073-2084, 2002.

30. Husemann Y, Geigl JB, Schubert F, et al: Systemic spread is an early step in breast cancer. Cancer Cell 13: 58-68, 2008.

31. Meng S, Tripathy D, Frenkel EP, et al: Circulating tumor cells in patients with breast cancer dormancy. Clin Cancer Res 10: 8152-8162, 2004.

32. Kallergi G, Mavroudis D, Georgoulias V and Stournaras C: Phosphorylation of FAK, PI-3K, and impaired actin organization in CK-positive micrometastatic breast cancer cells. Mol Med 13: 79-88, 2007.

33. Kallergi X, Kallergi G, Agelaki S, et al: Phosphorylated EGFR and PI-3K/Akt signaling kinases are expressed in circulating tumor cells of breast cancer patients. Breast Cancer Res 10: R80, 2008.

34. Lurje $\mathrm{G}$ and Lenz HJ: EGFR signaling and drug discovery. Oncology 77: 400-410, 2009

35. Lurje G, Schiesser M, Claudius A and Schneider PM: Circulating tumor cells in gastrointestinal malignancies: current techniques and clinical implications. J Oncol 2010: 392652, 2010.

36. Taubert H, Blumke K, Bilkenroth U, et al: Detection of disseminated tumor cells in peripheral blood of patients with breast cancer: correlation to nodal status and occurrence of metastases. Gynecol Oncol 92: 256-261, 2004.

37. Vona G, Sabile A, Louha M, et al: Isolation by size of epithelial tumor cells: a new method for the immunomorphological and molecular characterization of circulating tumor cells. Am J Pathol 156: 57-63, 2000.

38. Pinzani P, Salvadori B, Simi L, et al: Isolation by size of epithelial tumor cells in peripheral blood of patients with breast cancer: correlation with real-time reverse transcriptase-polymerase chain reaction results and feasibility of molecular analysis by laser microdissection. Hum Pathol 37: 711-718, 2006.

39. Muller V, Alix-Panabieres C and Pantel K: Insights into minimal residual disease in cancer patients: implications for anti-cancer therapies. Eur J Cancer 46: 1189-1197, 2010.

40. Deng G, Herrler M, Burgess D, Manna E, Krag D and Burke JF: Enrichment with anti-cytokeratin alone or combined with anti-EpCAM antibodies significantly increases the sensitivity for circulating tumor cell detection in metastatic breast cancer patients. Breast Cancer Res 10: R69, 2008.

41. Balic M, Dandachi N, Hofmann G, et al: Comparison of two methods for enumerating circulating tumor cells in carcinoma patients. Cytometry B Clin Cytom 68: 25-30, 2005.

42. Gertler R, Rosenberg R, Fuehrer K, Dahm M, Nekarda H and Siewert JR: Detection of circulating tumor cells in blood using an optimized density gradient centrifugation. Recent Results Cancer Res 162: 149-155, 2003. 
43. Stott SL, Lee RJ, Nagrath S, et al: Isolation and characterization of circulating tumor cells from patients with localized and metastatic prostate cancer. Sci Transl Med 2: 25ra23, 2010.

44. Flores LM, Kindelberger DW, Ligon AH, et al: Improving the yield of circulating tumour cells facilitates molecular characterisation and recognition of discordant HER2 amplification in breast cancer. Br J Cancer 102: 1495-1502, 2010

45. Allard WJ, Matera J, Miller MC, et al: Tumor cells circulate in the peripheral blood of all major carcinomas but not in healthy subjects or patients with nonmalignant diseases. Clin Cancer Res 10: 6897-6904, 2004

46. Mostert B, Kraan J, Bolt-de Vries J, et al: Detection of circulating tumor cells in breast cancer may improve through enrichment with anti-CD146. Breast Cancer Res Treat: April 9, 2010 (Epub ahead of print).

47. Fehm T, Solomayer EF, Meng S, et al: Methods for isolating circulating epithelial cells and criteria for their classification as carcinoma cells. Cytotherapy 7: 171-185, 2005

48. Ring AE, Zabaglo L, Ormerod MG, Smith IE and Dowsett M Detection of circulating epithelial cells in the blood of patients with breast cancer: comparison of three techniques. Br J Cancer 92: 906-912, 2005

49. Katz RL, He W, Khanna A, et al: Genetically abnormal circulating cells in lung cancer patients: an antigen-independent fluorescence in situ hybridization-based case-control study. Clin Cancer Res 16: 3976-3987, 2010.

50. Maheswaran S, Sequist LV, Nagrath S, et al: Detection of mutations in EGFR in circulating lung-cancer cells. N Engl J Med 359: 366-377, 2008

51. Cohen SJ, Punt CJ, Iannotti N, et al: Relationship of circulating tumor cells to tumor response, progression-free survival, and overall survival in patients with metastatic colorectal cancer. J Clin Oncol 26: 3213-3221, 2008.

52. Ntouroupi TG, Ashraf SQ, McGregor SB, et al: Detection of circulating tumour cells in peripheral blood with an automated scanning fluorescence microscope. Br J Cancer 99: 789-795, 2008.

53. Leversha MA, Han J, Asgari Z, et al: Fluorescence in situ hybridization analysis of circulating tumor cells in metastatic prostate cancer. Clin Cancer Res 15: 2091-2097, 2009.

54. Wu CH, Lin SR, Yu FJ, et al: Development of a high-throughput membrane-array method for molecular diagnosis of circulating tumor cells in patients with gastric cancers. Int J Cancer 19 373-379, 2006

55. Galanzha EI, Shashkov EV, Spring PM, Suen JY and Zharov VP In vivo, noninvasive, label-free detection and eradication of circulating metastatic melanoma cells using two-color photoacoustic flow cytometry with a diode laser. Cancer Res 69: 7926-7934, 2009

56. Kojima T, Hashimoto Y, Watanabe Y, et al: A simple biological imaging system for detecting viable human circulating tumo cells. J Clin Invest 119: 3172-3181, 2009.

57. Krivacic RT, Ladanyi A, Curry DN, et al: A rare-cell detecto for cancer. Proc Natl Acad Sci USA 101: 10501-10504, 2004.

58. Marrinucci D, Bethel K, Lazar D, et al: Cytomorphology of circulating colorectal tumor cells: a small case series. J Oncol 2010: 861341, 2010.

59. Reya T, Morrison SJ, Clarke MF and Weissman IL: Stem cells, cancer, and cancer stem cells. Nature 414: 105-111, 2001.

60. Vermeulen L, Sprick MR, Kemper K, Stassi G and Medema JP Cancer stem cells - old concepts, new insights. Cell Death Differ 15: 947-958, 2008.

61. Lin EH, Hassan M, Li Y, et al: Elevated circulating endothelial progenitor marker CD133 messenger RNA levels predict colon cancer recurrence. Cancer 110: 534-542, 2007.

62. Theodoropoulos PA, Polioudaki H, Agelaki S, et al: Circulating tumor cells with a putative stem cell phenotype in peripheral blood of patients with breast cancer. Cancer Lett 288: 99-106, 2010.

63. Tanaka F, Yoneda K, Kondo N, et al: Circulating tumor cells as a diagnostic marker in primary lung cancer. Clin Cancer Res 15 6980-6986, 2009.

64. Budd GT, Cristofanilli M, Ellis MJ, et al: Circulating tumor cells versus imaging - predicting overall survival in metastatic breast cancer. Clin Cancer Res 12: 6403-6409, 2006.

65. Moreno JG, Miller MC, Gross S, Allard WJ, Gomella LG and Terstappen LW: Circulating tumor cells predict survival in patients with metastatic prostate cancer. Urology 65: 713-718, 2005.
66. Stathopoulou A, Vlachonikolis I, Mavroudis D, et al: Molecular detection of cytokeratin-19-positive cells in the peripheral blood of patients with operable breast cancer: evaluation of their prognostic significance. J Clin Oncol 20: 3404-3412, 2002.

67. Ignatiadis M, Xenidis N, Perraki M, et al: Different prognostic value of cytokeratin-19 mRNA positive circulating tumor cells according to estrogen receptor and HER 2 status in early-stage breast cancer. J Clin Oncol 25: 5194-5202, 2007.

68. Allen-Mersh TG, McCullough TK, Patel H, Wharton RQ, Glover C and Jonas SK: Role of circulating tumour cells in predicting recurrence after excision of primary colorectal carcinoma. Br J Surg 94: 96-105, 2007.

69. Cohen SJ, Punt CJ, Iannotti N, et al: Prognostic significance of circulating tumor cells in patients with metastatic colorectal cancer. Ann Oncol 20: 1223-1229, 2009.

70. Halabi S, Small EJ, Hayes DF, Vogelzang NJ and Kantoff PW: Prognostic significance of reverse transcriptase polymerase chain reaction for prostate-specific antigen in metastatic prostate cancer: a nested study within CALGB 9583. J Clin Oncol 21: 490-495, 2003

71. Payne RE, Yague E, Slade MJ, et al: Measurements of EGFR expression on circulating tumor cells are reproducible over time in metastatic breast cancer patients. Pharmacogenomics 10 : $51-57,2009$

72. Liu Z, Jiang M, Zhao J and Ju H: Circulating tumor cells in perioperative esophageal cancer patients: quantitative assay system and potential clinical utility. Clin Cancer Res 13: 2992-2997, 2007.

73. Yen LC, Yeh YS, Chen CW, et al: Detection of KRAS oncogene in peripheral blood as a predictor of the response to cetuximab plus chemotherapy in patients with metastatic colorectal cancer. Clin Cancer Res 15: 4508-4513, 2009.

74. Yang MJ, Chiu HH, Wang HM, et al: Enhancing detection of circulating tumor cells with activating KRAS oncogene in patients with colorectal cancer by weighted chemiluminescent membrane array method. Ann Surg Oncol 17: 624-633, 2010

75. Larson CJ, Moreno JG, Pienta KJ, et al: Apoptosis of circulating tumor cells in prostate cancer patients. Cytometry A 62: 46-53, 2004.

76. Gradilone A, Petracca A, Nicolazzo C, et al: Prognostic significance of survivin-expressing circulating tumour cells in T1G3 bladder cancer. BJU Int 106: 710-715, 2010.

77. Yoon SO, Kim YT, Jung KC, Jeon YK, Kim BH and Kim CW: TTF-1 mRNA-positive circulating tumor cells in the peripheral blood predict poor prognosis in surgically resected non-small cell lung cancer patients. Lung Cancer: May 13, 2010 (Epub ahead of print).

78. Barbu V, Bonnand AM, Hillaire S, et al: Circulating albumin messenger RNA in hepatocellular carcinoma: results of a multicenter prospective study. Hepatology 26: 1171-1175, 1997.

79. Bessa X, Pinol V, Castellvi-Bel S, et al: Prognostic value of postoperative detection of blood circulating tumor cells in patients with colorectal cancer operated on for cure. Ann Surg 237: 368-375, 2003

80. Meng S, Tripathy D, Shete S, et al: HER-2 gene amplification can be acquired as breast cancer progresses. Proc Natl Acad Sci USA 101: 9393-9398, 2004.

81. Meng S, Tripathy D, Shete S, et al: uPAR and HER-2 gene status in individual breast cancer cells from blood and tissues. Proc Natl Acad Sci USA 103: 17361-17365, 2006

82. Wulfing P, Borchard J, Buerger H, et al: HER2-positive circulating tumor cells indicate poor clinical outcome in stage I to III breast cancer patients. Clin Cancer Res 12: 1715-1720, 2006.

83. Pestrin M, Bessi S, Galardi F, et al: Correlation of HER2 status between primary tumors and corresponding circulating tumor cells in advanced breast cancer patients. Breast Cancer Res Treat 118: 523-530, 2009.

84. Slade MJ, Payne R, Riethdorf S, et al: Comparison of bone marrow, disseminated tumour cells and blood-circulating tumour cells in breast cancer patients after primary treatment. Br J Cancer 100: 160-166, 2009.

85. Smith SL and Rajan PS: Imaging of pancreatic adenocarcinoma with emphasis on multidetector CT. Clin Radiol 59: 26-38, 2004.

86. De Giorgi U, Valero V, Rohren E, et al: Circulating tumor cells and $[18 \mathrm{~F}]$ flurodeoxyglucose positron emission tomography/ computed tomography for outcome prediction in metastatic breast cancer. J Clin Oncol 27: 3303-3311, 2009. 